\title{
Accounting
}

\section{Factors affecting the use of derivative financial instruments of listed companies: The case of Hanoi Stock Exchange}

\author{
Trong Lam Vu , Cong Thanh Le ${ }^{b}$, Ngoc Anh Pham ${ }^{c^{*}}$ and Thi Ngoc Ha Tranc
}

\author{
${ }^{a}$ Communist Review, Vietnam \\ ${ }^{b}$ Thai Binh University, Vietnam \\ C H R O N I C L E \\ Article history: \\ Received March 102020 \\ Received in revised format March \\ 152020 \\ Accepted May 302020 \\ Available online \\ June 12020 \\ Keywords: \\ Derivative financial instruments \\ Hanoi Stock Exchange \\ Vietnam
}

${ }^{c}$ University of Economics - Technology for Industries, Vietnam

\begin{abstract}
A B S T R A C T
The objective of this paper is to assess the factors affecting the intention to use derivative financial instruments (DFIs) in Hanoi Stock Exchange, Vietnam. The study was conducted on 356 enterprises listed on the Hanoi Stock Exchange and the results show that Perception, Misuse, Expertise, risk management controls and Benefits had positive impacts on the intention to use the DFIs. In this survey, the risk management controls factor maintains the strongest impact on the intention to use FDIs of the enterprises. Finally, the study conducted multi-group analysis by groups; including Gender, Education and Position held with firms.
\end{abstract}

\section{Introduction}

Vietnam is a dynamic market of the Asia-Pacific region, with a growth rate of nearly $6 \%$ in recent years and the size of the economy of about US $\$ 200$ billion (Antono et al., 2019; Dang et al., 2019; Bui, 2020). After 30 years of open integration and development, Vietnam's economy has grown steadily and positively integrated into the global economy (Nguyen et al., 2020). Vietnam's global trade activities are also expanding, with more than 200 trading partners, including 70 countries with trade turnover of more than US \$ 100 million. In 2000, Vietnam opened its stock market and in 2009 set up a specialized bond market. On August 10, 2017, Vietnam opened the derivatives market, one of three important pillars in the structure of a modern stock market. Financial derivative instruments were quickly known on both the Hanoi Stock Exchange and the Ho Chi Minh Stock Exchange. With the speed of economic development and deep integration with the global economy, Vietnamese enterprises are inevitably affected and exposed to the risks of market factors such as changes in exchange rates and prices both goods in the market, interest rates, changes of financial markets and securities (Nguyễn Thu Thủy, 2017; Xuan et al., 2020). However, according to Trần Mạnh Dũng (2014), the application of DFIs as well as accounting of financial derivative instruments is really considered a challenge for businesses in the first years of application.

Finding hedging solutions is a great demand for businesses. Financial derivative instruments were created to allow businesses to hedge risks and have become an attractive investment channel for investors, a channel to raise capital for the economy. Many

* Corresponding author.

E-mail address: ptthien.kt@uneti.edu.vn (N. A. Pham) 
countries around the world, especially those with developed economies, have widely used DFIs. In Vietnam, there are still very few businesses, including import-export enterprises, using financial derivative instruments to prevent risks. Vietnam is determined to participate in the global supply chain, expand economic cooperation and international trade and perfect the modern market economy institution. This context has encouraged Vietnamese import-export enterprises to use financial derivative instruments to prevent and limit risks, making a positive contribution to the economy. The implementation of financial derivative instruments of businesses in general, including those listed on the stock market is affected (impact) by the factors that are the topics of deep concern. Accordingly, based on the degree of influence of the factors on the use will be a basis for the research team to make recommendations to promote the use of derivative financial instruments, thereby preventing and limiting risk management in businesses listed on Hanoi Stock Exchange of Vietnam (Tran et al., 2019).

The layout of the article in addition to the introduction includes: Overview of research, research methods, research results and conclusions.

\section{Literature review}

\subsection{Derivative financial instruments}

The derivative financial instrument (DFI) has a long development process, starting in the 80s of the 20th century and it marked the development of the trend of financial innovation. According to Bezzina and Grima, (2011) a derivative contract is understood to be a financial contract with value attached to the price of goods, raw materials, assets, exchange rates, indices, events or the scale of the conditions stated in the contract. According to John (1992), a derivative financial instrument is a valuable contract that depends on the performance of an original financial asset, an index or other investment instrument. In accordance with U.S. Financial Accounting Standard 133 on derivative financial instruments and hedging instruments, derivative financial instruments have one or more underlying assets and one or more capital amounts combined with into one block. According to International Accounting Standard No. 39 - Measurement and recognition of financial instruments, derivative financial instruments are considered to be contracts with value changes according to changes of market factors (underlying assets). facility). Derivative financial instruments have low or nearly zero initial investments and derivative financial instruments are paid out at a future date.

Based on different criteria, derivative financial instruments are divided into specific categories. Classification according to characteristics and nature of derivative contracts, including: forward contracts, futures contracts, swap contracts and options contracts. Classifying by payment method, derivative financial instruments include: financial derivative instruments transferred with derivative instruments and derivative financial instruments. Classification by reference assets, including interest rate derivative financial instruments, monetary derivative financial instruments, commodity derivative financial instruments, and securities derivative financial instruments. Finally, classify derivative financial instruments according to their intended use, includes hedging derivatives and hedging financial instruments for commercial purposes.

The nature of a financial instrument is a contract in which the contracting parties agree directly or with the issuer on how to exchange cash flows or other financial instruments in the future. The payment and exchange of cash flows or other financial instruments represents the financial relationship between the contracting parties and is the basis for deciding the nature of the financial instrument. The value of a financial instrument depends on the issuer's payment commitment, liquidity as well as market factors.

A derivative financial instrument (DFI) is a type of financial instrument, which has the general characteristics and characteristics of a financial instrument and at the same time has a particular feature that is a financial instrument formed on an original basis derivative (reference assets such as stocks, bonds, commodities, foreign currencies ...). DFI is primarily designed to prevent risks when investors estimate risks that may arise in the future when the fair value of derivative changes, and DFI also meets the needs. trading for investors wishing to make a profit on the changing market factors.

\subsection{Useful information theory}

According to some studies by Sterling (1970): Information theory useful for economic decision making provides financial information are related to enterprises to use in decision making. The characteristics of useful information theory are: (i) full disclosure of information to help organizations make economic decisions; (ii) managing the economic resources of an organization more appropriately; (iii) maintain and communicate information to users via FR; and (iv) use accounting information to evaluate or make an ability to predict the future problems of an organization such as profitability, cash flow, bankruptcy, etc. to benefit the Market participants and create conditions for markets to operate efficiently, develop economically and bring benefits to the society.

In the accounting field, the publication of adequate and qualitative accounting information is considered to be useful information and must meet the market prices of products, goods and services. In this study, market prices are governed by market factors. 
The market is a place of trading of products, goods, exchange rates, interest rates. Therefore, accounting information must reflect the current market situation through price and quality. DFI accounting requires derivative products to be measured, assessed and monitored at market prices. If so, the market is the bridge between the bookkeeping price and the market price; between the information transmitter and the receiver; At the same time, it depends on the value of information so that enterprises can partly allocate economic resources efficiently, partly predict the change of the market, thereby being able to cope with the sudden changes of the market. market (Beaver et al., 1968).

\subsection{Signal theory}

Signal theory was born in 1973, from economics in terms of information asymmetry (Tirole, 1988; Thuy et al., 2019). In the field of accounting, the asymmetric information situation leads to two problems:

Firstly, the accounting information is not fully displayed by the enterprise on financial reporting (FR), or it is possible that the information presented and published by the enterprise is not of quality assurance. This situation may be due to the accountant's inadequate professional skills, in-depth knowledge to handle practical issues within the entity and, or the inadequate administrator to conduct FR information. amount. If so, the factor that makes the accountant when making accounting reports related to DFI has a great impact on FR quality. In this study, in order to minimize information asymmetry, if the accountant is able to apply and handle DFI accounting well, high knowledge and expertise will greatly impact the application of public accounting. Derivative financial instruments lead to transparent, reliable and quality FR. In contrast, if the accountant is not familiar with the DFI accounting regulations, or because the subjectivity of the accountant not only affects the application of DFI accounting, it also affects accounting information. useful.

Second, the motivation of an administrator in disclosing information, because an administrator has the most benefit in terms of information, means that the administrator is the object of information provision and has an exclusive right to provide information. Therefore, the administrator will provide information to the outside most beneficial to the administrator and the business. Both of these issues not only make it difficult for accounting information users on FR to make economic decisions but also lead to underdevelopment of markets. In the current study, if the administrator does not provide or provides accounting information derivative financial instruments incomplete due to the purpose of the administrator or accounting system lack of participation and cooperation of the house management, or the administrator is not knowledgeable, or is not aware of the importance of accounting information derivative financial instruments may lead to (i) published accounting information will not be useful to the Using the accounting, (ii) accountants have difficulty in applying derivative financial accounting.

\subsection{Enterprise resource theory}

According to the theory of enterprise resources (Wernerfelt, 1984), the focus is on analyzing: (1) tangible resources such as financial resources that are owner's equity and funding; (2) Intangible resources including knowledge and skills of managers, employees, etc. and this theory is the basis for decision making to create business efficiency for businesses with intangible resources and human resources.

In the field of accounting, from the enterprise's perspective, the training and upgrading of professional skills for the current team and the inheritance team are necessary to ensure expertise, knowledge, ability to apply, and ability to update knowledge for both accountants and administrators. In this study, in order for accountants to apply accounting derivative financial instruments conveniently in addition to training and retraining for the current accounting, the team must also train and foster the inheritance team and it is necessary for house management to have sufficient knowledge, expertise, and profession, the accountant can comply with professional ethics, organize the management of the accounting system, set up FR compliance, accounting regime and accounting standards to ensure quality of services. At the same time, the manager also needs good expertise to coordinate, organize and manage the accounting system closely to ensure the published FR reaches the best quality.

Along with the theory of enterprise resources, there is the theory of corporate governance. The theory of corporate governance aims to establish relationships between managers, shareholders and stakeholders in order to achieve the overall goals of the organization, through means of supervision and control (Mason et al., 2007). The effectiveness of the control is manifested through the quality of information published in the FR that raises concerns among parties and forms the basis for economic decision making (John, 1992). The attribute of business management theory is about the human factor and the operational efficiency factor of an organization.

\subsection{Factors affecting the use of derivative financial instruments}

\section{Perception}

According to Sharma (2009) derivative financial instruments are said to have a negative impact on the economy. The derivatives trading market is a virtual, bogus and fraudulent market (Das, 2006). There are even studies that derive financial instruments as financial instruments leading to financial losses or financial failures (Hull, 2008). Dodd (2002) argues that derivative financial 
instruments are the worst financial instruments wasting time and money for investors and businesses. Many researchers and business owners are negatively aware of the usefulness of derivative financial instruments (Adams \& Runkle, 2000).

In fact, the general view of most economists worldwide is that derivative instruments have been a positive innovation in the last 30 years (Cochran, 2007) due to a significant part of financial innovation which has come from the emergence of a derivative market (Acharya et al., 2009). Recently, the trading and exchange of derivative financial instruments on the stock market and on the OTP market has been very active. According to Stulz (2005), derivative financial instruments are not only proven to be of great value to modern economies when handled carefully, but they are also tools for profitability and control, effective risk for businesses, especially for large enterprises with import-export activities and listed on the stock exchange.

\section{Benefits}

When used for the right purposes, the right derivative financial instruments will bring benefits to businesses (Stulz, 2005). The two most important benefits that derivative financial instruments bring are risk management and price control (CFA, 2009). Risk management is the process involved in determining the ideal level of risk, determining the level of existing risks and the ability to control to minimize the losses caused by risks. Derivative financial instruments are often used to hedge the risks of investing and derivative financial instruments themselves are used to invest.

Investors tend to combine hedging and speculation strategies together to limit potential losses and manage risk more effectively (CFA, 2009). Price control is the process of determining the spot price of a particular commodity or stock. Prices are influenced by supply and demand factors, including current and future prices of underlying assets based on derivative contracts. An effective price control process is a process characterized by the rapid adjustment of market prices from the old equilibrium to the new equilibrium with the emergence of new information. Therefore, the market price for the future depends on data flows from different regions around the globe and therefore this requires a high degree of transparency (CFA, 2009).

\section{Misuse}

Misuse of derivative financial instruments are also a factor mentioned by many previous studies. This boom depends on increasing lending and increasing bad debt, which is then sold through the short sale of any derivative financial instruments. This creates a debt pyramid since the value of the sold debt is not really known. According to Davidson (2000), investors and traders lose money because they do not know how the derivative works, in addition, companies do not have the necessary internal control measures to protect their assets in this high-risk area. Some investors exchanged errors with the media for failing to provide enough information on derivative financial instruments that led people to believe that derivative financial instruments were not problems caused by investors. According to Davidson (2000) derivative financial instruments can be a weapon to hedge risks, but investing in derivative financial instruments is like gambling.

The above arguments show that the various factors that hinder the use of derivative instruments properly and blame the derivative instruments for financial damage and the global economic recession more broadly like blame for a car that causes the accident, instead of the drunk driver (Bartram, 2009).

\section{Expertise}

According to Blanc (1995) senior leaders must ensure proper education for those responsible for derivative financial instruments. According to Cowan (1994), although education helps people to better understand derivative financial instruments, reduce fear of these instruments, it still takes a long time to change the perspective of financial instruments. A survey conducted by KPMG among financial managers and investors showed a lack of in-depth knowledge about derivative instruments and risk management (Pengelly, 2008). Lack of professional knowledge in handling derivative instruments is one of the main reasons for not using derivative tools (Ameer et al., 2011; Cummins et al., 2001; Pham et al., 2020).

\section{Risk management controls}

One way to use derivative financial instruments effectively is to manage risks and control risks for businesses. Derivative financial instruments are used to solve problems related to credit risk, operational risk and market risk. In addition, derivative financial instruments are also used to control other risks such as liquidity risk, system risk and legal risk (Babak, 2008).

In addition, demographic variables such as gender, professional qualifications of accountants or administrators also have a very different impact on the intention to use derivative financial instruments of enterprises in general and enterprises. Listed enterprises in particular. 


\subsection{Background and research sample}

Stock exchanges play an important role in a country's economic activities. Stock exchanges help companies raise capital for expansion and development. It also gives individuals the opportunity to invest in companies. In addition, the stock exchange also provides regulations for stock trading and is the place to create hundreds of thousands of job opportunities for people. The stock exchange helps companies raise capital to expand and grow their business. When a company needs to raise capital, it will sell the stock by listing it on a stock exchange. Investors can buy shares and the proceeds from the investors will be used by the company to expand business, buy another company or recruit more workers. The stock exchange allows individuals to invest in any company in the world. Big and small investors all go through stock exchanges to buy stocks of companies. The middleincome people will also have the opportunity to buy shares, which helps investors to be more confident in spending money on economic activities. The stock exchange provides regulations on stock trading. Thanks to the regulations and measures to protect shareholders, people feel more confident investing in this field. Investors' wealth will grow over time and this will help them contribute more to the economy. Stock exchanges and related companies such as brokers, investment banks and financial institutions employ hundreds of thousands of workers. Most of the jobs related to securities are highly paid and have many promotion opportunities. The Hanoi Stock Exchange is the most important stock exchange in Vietnam. With the market capitalization scale growing steadily over the years, up to now, it has reached 192 trillion VND, 100 times more than the end of 2005 (the time of establishing the trading floor). Liquidity of the HNX market, though volatile, has been on the uptrend. In addition to the development of market size, changes in mechanisms and trading methods (applying the continuous order matching mechanism, extending the trading time in a session, adding periodic order matching mechanism to confirm opening, closing prices ...) also boosted liquidity in the stock market. The value of blade transactions has reached a record with a value of more than VND 1,000 billion. For 15 years, listed companies on the HNX have raised more than VND 109,677 billion to the HNX through investment, production, business and creation of material wealth for society through the issuance of shares on the market. stock market.

To assess the factors affecting the intention to use derivative financial instruments of enterprises listed on the Hanoi Stock Exchange, we have sent the questionnaires via email and by mail or directly to 400 businesses listed on the Hanoi Stock Exchange. For 3 consecutive weeks we conducted a phone call, exchange and have businesses fill out the survey. After 3 weeks, we collected 388 surveys, accounting for $97 \%$ of a very good number. Next, we cleaned the data, filtered the missing and invalid questionnaires, the remaining 356 questionnaires met the conditions to be included in the next analysis.

\subsection{Research models}

Fig. 1 shows the proposed study of this paper

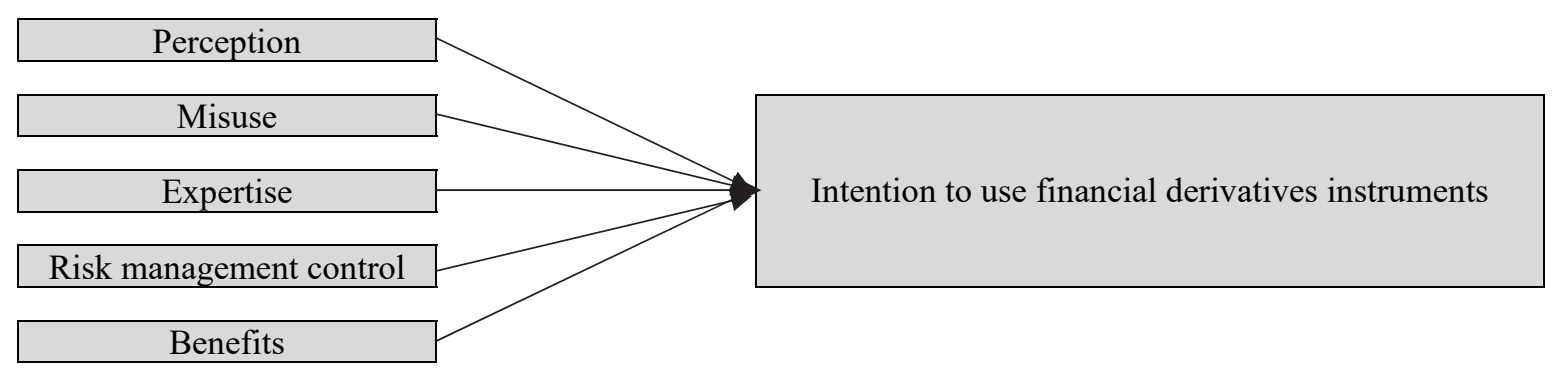

Fig. 1. The proposed study

Based on the results of the research review, we have selected 5 factors that influence the intention to use derivative financial instruments to include in the testing model: Perception, Misuse, Expertise, risk management. controls and Benefits.

where

Perception is measured by 4 items developed from the study of Sharma (2008); Hull (2008) and Acharya et al. (2009). These scales are measured by a 5 -point Likert scale from 1 that fully agree to 5 totally disagree.

Misuse: Measured by 4 items developed from Davidson (2000). These scales are measured by a 5-point Likert scale from 1 that fully agree to 5 totally disagree.

Expertise: Measured by 5 items developed inherited from Pengelly's study (2008). These scales are measured by a 5-point Likert scale from 1 that fully agree to 5 totally disagree.

Risk management controls: Measured by 9 items developed inherited from Babak (2008). These scales are measured by a 5point Likert scale from 1 that fully agree to 5 totally disagree. 
Benefits: Measured by 4 items developed inherited from Stulz's research (2005). These scales are measured by a 5-point Likert scale from 1 that fully agree to 5 totally disagree.

Intention to use derivative financial instruments: Measured by 5 items developed from Bezzina and Grima (2011). These scales are measured by a 5 -point Likert scale from 1 that fully agree to 5 totally disagree.

Research hypotheses:

H1: Benefit has positive impact on intention to use derivative financial instruments.

$\mathrm{H} 2$ : Expertise has positive impact on intention to use derivative financial instruments.

H3: Misuse has positive impact on intention to use derivative financial instruments.

H4: Perception has positive impact on intention to use derivative financial instruments.

H5: Risk management controls has positive impact on intention to use derivative financial instruments.

\subsection{Analytical techniques}

To ensure the reliability of the scales in the questionnaire, the researcher uses the Cronbach Alpha coefficient (implemented on SPSS 22.0 software) in testing the suitability of the scales, with the required coefficient. This value must be $>0.6$ and the total correlation coefficient> 0.3 (Hair et al., 2013, 2011, 2014, 2017) to accept the use of scales for further analysis.

+ Analysis of discovery factors - EFA

The analytical option chosen by the researcher is to perform exploratory factor analysis (EFA) for each factor according to the theoretical model. Selection criteria: factor loading factor $\geq 0.5$; The scale is satisfactory when the total variance extracted (Cumulative\%) $\geq 50 \%$; To implement EFA, it is necessary to check KMO $\geq 0.5$ and Eigenvalue $\geq 1$ (Henseler et al., 2009, 2015).

Exploration factor analysis is conducted in the following order: (i) analyzing all the questions of the impact and impacted factors separately; (ii) perform a questionnaire that does not meet the technical requirements (the questionnaire has two load factors with a distance not greater than 0.2 ; the question item stands alone for a factor).

+ Correlation and regression analysis

By identifying the impact factors and the factors affected, we built a research model written in the form of the regression equation as follows:

$y=\beta_{0}+\beta_{1} x_{1}+\beta_{2} x_{2}+\beta_{3} x_{3}+\beta_{4} x_{4}+\beta_{5} x_{5}+\varepsilon$,

where $y$ is dependent variable - intention to use derivative financial instruments in enterprises listed on Hanoi Stock Exchange Vietnam, $\beta_{0}$ is Intercept and $\beta_{1}, \beta_{2}, \beta_{3}, \beta_{4}$ and $\beta_{5}$ are regression coefficients precede corresponding variables

$$
\mathrm{x} 1 \text { : Perception } \quad \mathrm{x}_{2} \text { : Misuse } \quad \mathrm{x}_{3} \text { : Expertise } \quad \mathrm{x}_{4} \text { : Risk management controls } \quad \mathrm{x}_{5} \text { : Benefits }
$$

$\varepsilon$ : Errors in the model.

To test the research hypotheses, we use bootstrap technique in Smart PLS 3.6 software.

\section{Research results}

The results of the reliability test of the scale on SPSS 22 software show that all items meet the reliability condition, have Cronbach Alpha coefficient $>0.7$ and total correlation coefficient $>0.4$. However, there are 2 items which are risk control variables 4 and 7 that have a correlation coefficient of total variables $<0.3$, so we leave the research model. Next, we conducted EFA discovery factor analysis, showing that all factors have factor loading factor $>0.5$ and extract 6 factors. Next, we conducted a composite evaluation of models, data and tested the research hypotheses on Smart PLS 3.6. The results of the general reliability test of the scale of potential variables are shown in Table 1. According to Henseler et al. (2009) the overall Cronbach's Alpha coefficient must be $>0.7$ in the model of all Cronbach's Alpha values $>0.8$, which is a very good result. In addition, AVE is Hair et al. $(2013,2011,2014)$ and Henseler et al $(2009)$ recommend that $>0.5$ satisfy the analytical condition. The article shows that all AVE values are $>0.63$. 
Table 1

Construct Reliability and Validity

\begin{tabular}{lcccc}
\hline & Cronbach's Alpha & rho_A & Composite Reliability & $\begin{array}{c}\text { Average Variance } \\
\text { Extracted (AVE) }\end{array}$ \\
\hline Benefits & 0.872 & 0.872 & 0.872 & 0.694 \\
Expertise & 0.898 & 0.898 & 0.898 & 0.638 \\
Intention to use derivative financial instruments & 0.981 & 0.981 & 0.981 & 0.669 \\
Misuse & 0.911 & 0.911 & 0.911 & 0.672 \\
Perception & 0.910 & 0.911 & 0.910 & 0.629 \\
Risk management controls & 0.928 & 0.928 & 0.928 & 0.682 \\
\hline
\end{tabular}

\section{Table 2}

Discriminant Validity (Fornell-Larcker Criterion)

\begin{tabular}{|c|c|c|c|c|c|c|}
\hline 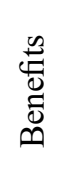 & 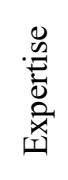 & 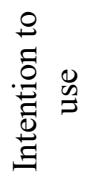 & 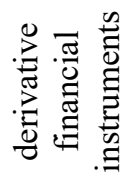 & 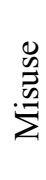 & :0ี & 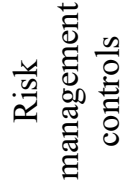 \\
\hline
\end{tabular}

\begin{tabular}{lllllll}
\hline Benefits & $\mathbf{0 . 8 3 3}$ & & & & & \\
Expertise & 0.022 & $\mathbf{0 . 7 9 9}$ & & & \\
Intention to use derivative financial instruments & 0.016 & 0.038 & $\mathbf{0 . 8 1 8}$ & & \\
Misuse & 0.067 & 0.010 & 0.012 & $\mathbf{0 . 8 2 0}$ & & \\
Perception & 0.037 & 0.049 & 0.041 & 0.020 & $\mathbf{0 . 7 9 3}$ & $\mathbf{0 . 8 2 6}$ \\
\hline Risk management controls & 0.094 & 0.026 & 0.021 & 0.588 & 0.030 & \\
\hline
\end{tabular}

According to Henseler (2009) the diagonal coefficients in the Discriminant Validity result must be greater than all other values. According to the results in Table 2, it is shown that the maximum value (outside the diagonal) is 0.588 , which is also smaller than the smallest value on the diagonal of 0.793 so the differential values are guaranteed.

Table 3

Fit Model Summary

\begin{tabular}{|c|c|c|}
\hline & Saturated Model & Estimated Model \\
\hline SRMR & 0.058 & 0.059 \\
\hline d_ULS & 0.963 & 1.022 \\
\hline d_G & 0.461 & 0.491 \\
\hline Chi-Square & $1,695.642$ & $1,718.791$ \\
\hline NFI & 0.885 & 0.890 \\
\hline
\end{tabular}

\section{Table 4}

The results of F-Square

\begin{tabular}{|c|c|c|c|c|c|c|}
\hline & Benefits & Expertise & $\begin{array}{l}\text { Intention to use derivative } \\
\text { financial instruments }\end{array}$ & Misuse & Perception & $\begin{array}{l}\text { Risk management } \\
\text { controls }\end{array}$ \\
\hline Expertise & & & 0.219 & & & \\
\hline \multicolumn{7}{|c|}{ Intention to use derivative financial instruments } \\
\hline Perception & & & 0.192 & & & \\
\hline Risk management controls & & & 0.211 & & & \\
\hline
\end{tabular}

The value of f-square shows that the factors in the research model are closely related and consistent with the research data.

Hypothesis test results

The summary of hypotheses testing results are presented in Table 5 below.

Table 5

The results of path coefficients

\begin{tabular}{|c|c|c|c|c|c|}
\hline & $\begin{array}{c}\text { Original } \\
\text { Sample }(\mathrm{O}) \\
\end{array}$ & $\begin{array}{c}\text { Sample } \\
\text { Mean (M) }\end{array}$ & $\begin{array}{c}\text { Standard Deviation } \\
\text { (STDEV) }\end{array}$ & $\begin{array}{c}\text { T Statistics } \\
(|\mathrm{O} / \mathrm{STDEV}|) \\
\end{array}$ & $\begin{array}{c}\mathrm{P} \\
\text { Values } \\
\end{array}$ \\
\hline Benefits $\rightarrow$ Intention to use derivative financial instruments & 0.132 & 0.132 & 0.004 & 32.106 & 0.000 \\
\hline Expertise $\rightarrow$ Intention to use derivative financial instruments & 0.203 & 0.203 & 0.003 & 67.672 & 0.000 \\
\hline Misuse $\rightarrow$ Intention to use derivative financial instruments & 0.207 & 0.207 & 0.004 & 53.719 & 0.000 \\
\hline Perception $\rightarrow$ Intention to use derivative financial instruments & 0.239 & 0.239 & 0.003 & 77.169 & 0.000 \\
\hline Risk management controls $\rightarrow$ Intention to use derivative financial instruments & 0.252 & 0.252 & 0.005 & 48.156 & 0.000 \\
\hline
\end{tabular}


From the results of the hypothesis test, all theories are supported (See Fig. 2).

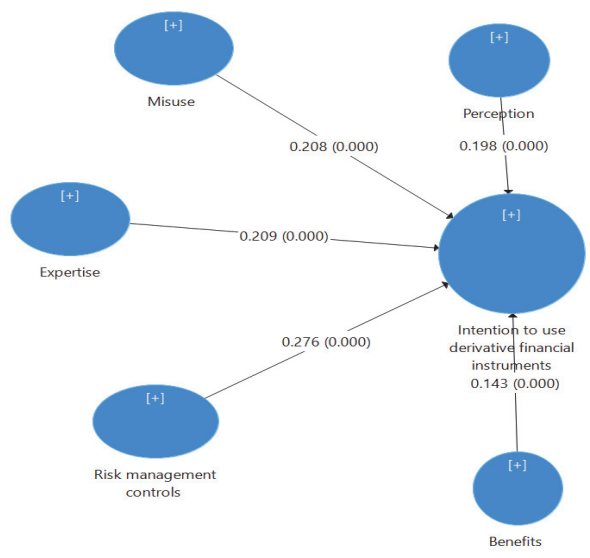

Fig. 2. Research hypothesis test results

From the results of Fig. 2, all 5 factors have positive impacts on the intention to use derivative financial instruments. In particular, the Risk management controls factor has the strongest impact with the coefficient of 0.276 at $1 \%$ significance level $\left(\mathrm{P}_{-}\right.$value $=$ 0.000). That means that the purpose of risk control will strongly influence the intention to use derivative financial instruments. Indeed, derivatives are now quite popular in the world and in Vietnam today, especially for import-export enterprises and listed enterprises. Derivative financial instruments are considered as a very effective hedge. Therefore, risk control has a strong impact on the intention to use derivative financial instruments of enterprises listed on the Hanoi Stock Exchange. The next factor is the qualification of accountants and administrators. The more qualified the administrators and accountants are, the higher the level of internal control and understanding of derivative financial instruments. Therefore, the intention to use derivative financial instruments will be higher. The Misuse factor has a fairly strong impact on the intention to use derivative financial instruments at the impact level of 0.208 at the $1 \%$ significance level $(\mathrm{P}$ _value $=0.000)$. The Perception factor influences the intention to use derivative instruments at the impact level of 0.198 at the $1 \%$ significance level $\left(\mathrm{P}_{-}\right.$value $\left.=0.000\right)$. Finally, the perceived benefit that the derivative financial instrument maintains the least impact with an impact coefficient of 0.143 at $1 \%$ significance level $\left(\mathrm{P}_{\text {_value }}=0.000\right)$. The above results show that the role of derivative financial instruments has been of interest to businesses listed on the Hanoi Stock Exchange. These firms primarily use derivative financial instruments with the purpose of risk prevention, followed by their knowledge, managers and internal control understand the role and effect of derivative financial instruments so they will actively use this tool. The next important factor is Misuse. In Vietnam, institutional and legal characteristics of derivative financial instruments are incomplete, so misuse has a strong impact on the intention to use derivative financial instruments. Most of Vietnamese investors still do not have good knowledge about derivative financial instruments, therefore, those who have a fairly good understanding of derivative financial instruments have more intention to use them.

Multi-gender testing Gender

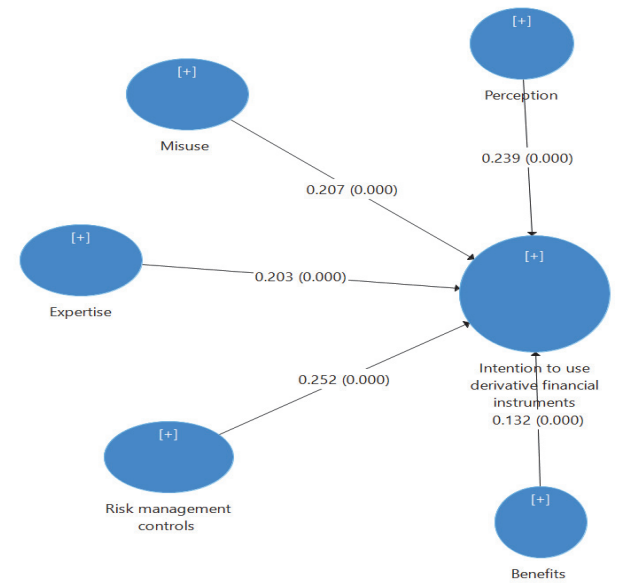

Fig. 3. Results of multi-group analysis with male group

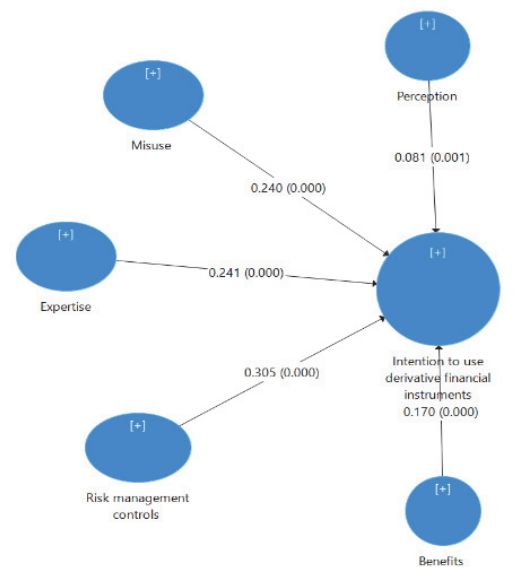

Fig. 4. Results of multi-group analysis with female gender group 
From the results of multi-group analysis in Fig. 3 and Fig. 4, we understand that, with the impact of the demographic variable, gender makes a difference on the overall research model. In the overall research model in Fig. 2, the purpose of risk control only affects the intention to use derivative financial instruments is 0.276 at $1 \%$ significance level $\left(P_{-}\right.$value $\left.=0.000\right)$. However, in the group that only considered females, the purpose of controlling risks strongly affects the intention to use derivative financial instruments with an impact coefficient of 0.305 at the $1 \%$ significance level $\left(\mathrm{P}_{-}\right.$value $\left.=0.000\right)$, while in the group with only male gender, the impact coefficient is 0.252 at the $1 \%$ significance level $\left(\mathrm{P} \_\right.$value $\left.=0.000\right)$. Especially in terms of awareness, for the South, the perception of derivative financial instruments has a strong impact on the intention to use derivative financial instruments. In contrast to the Female group, the awareness of derivative financial instruments is limited so the impact coefficient is very small, only 0.081 at $1 \%$ significance level $\left(P_{-}\right.$value $\left.=0.001\right)$.

\section{Multi-group analysis by Education}

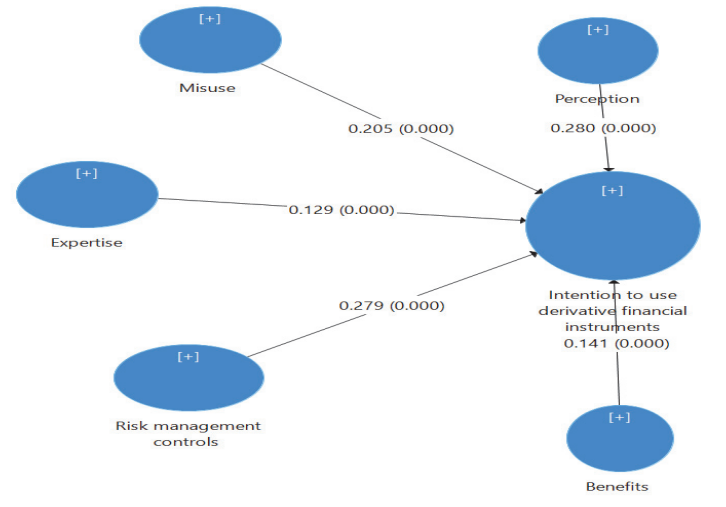

Fig. 5. Results of multi-group analysis with college-level group

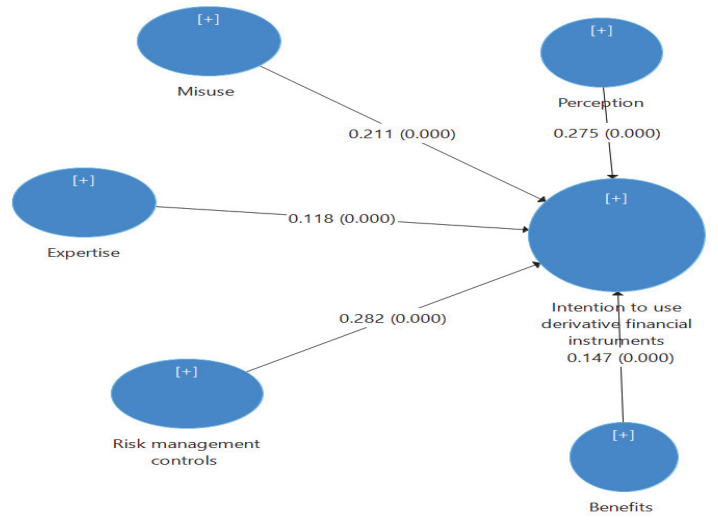

Fig. 6. Results of multi-group analysis with group of university and post-graduate

According to the qualifications of managers and accounting professionals, internal auditors and internal controllers are divided in two groups of college and university, and postgraduate. According to this subgroup, there is no significant difference between the two groups. Since investors and executives who have held important positions such as chief financial officer, chief accountant, director, controller have the same level of market knowledge of financial instruments. Therefore, in our study, we found no significant difference between the two groups when they are divided by subject level. Finally, we conduct multi-group analysis by position in the enterprise

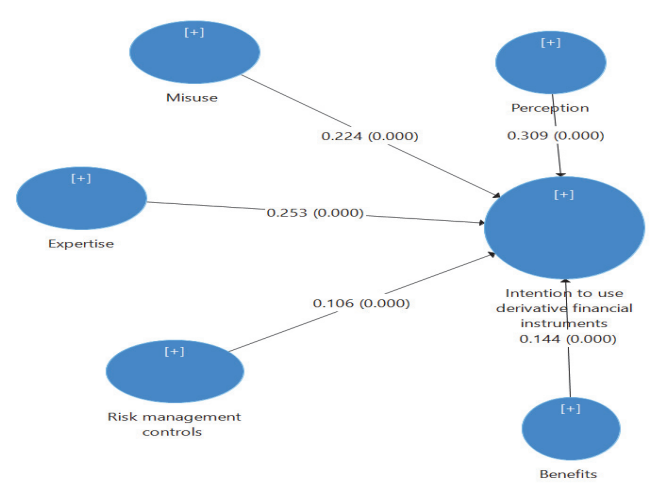

Fig. 7. Results of multi-group analysis with group of employee positions

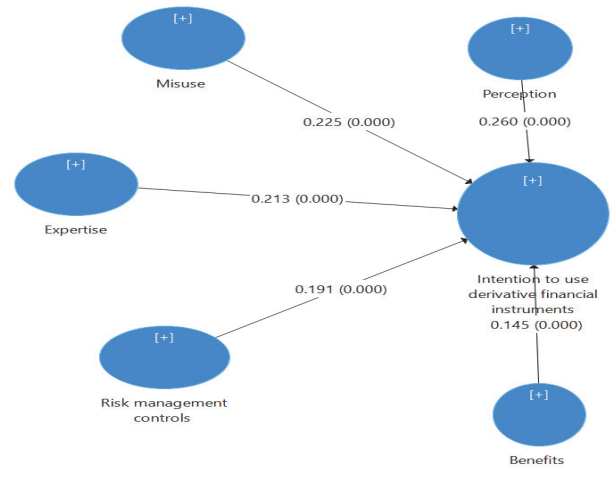

Fig. 8. Results of multi-group analysis with the CEO position team

The basic difference between CEOs and accountants, controllers, and internal auditors is about the specialized level of finance and accounting. For employees, due to the nature of the work, they need to have a deep understanding of derivative financial instruments, so the impact of qualification on the intention to use derivative financial instruments is higher than that of the CEO $(0.253>0.213)$ and at the same significance level of $1 \%\left(P_{-}\right.$value $\left.=0.000\right)$ and the employees' awareness of derivative financial 
instruments is also more than the CEO $(0.309>0.260)$ at the same significance level of $1 \%\left(\mathrm{P}_{-}\right.$value $\left.=0.000\right)$ which makes perfect sense. Because, employees must learn specific details, professional skills can be more in-depth than CEOs, however, strategic vision and ability to cover managers will be better. In contrast to the $\mathrm{CEO}$, the purpose of using derivative financial instruments to prevent risks $(0.191>0.106)$ at the same significance level of $1 \%\left(\mathrm{P}_{-}\right.$value $\left.=0.000\right)$. In Vietnam, derivative financial instruments have not been widely developed, as the regulations and sanctions for manual and monitoring are still incomplete. Therefore, most of the time, derivative financial instruments is used for hedging purposes for businesses, especially those listed on the stock exchange.

\section{Conclusion}

Based on the results of the survey, the research conducted regression analysis, bootstrap test and multi-group test. The results have shown that, among 5 independent factors analyzed, all 5 factors, namely Perception, Misuse, Expertise, risk management controls and Benefits, influenced the decision to use derivative financial instruments of enterprises listed on the Hanoi Stock Exchange. In particular, the perception of the purpose of risk prevention was the strongest impact and the least impact was the benefits factor.

Based on the research results, the research team proposed some recommendations to increase the use of derivative financial instruments in Vietnamese enterprises in general and enterprises listed on the Hanoi Stock Exchange private.

For businesses listed on the Hanoi Stock Exchange, it is necessary to improve the qualifications and quality of human resources, especially for corporate management personnel, who play an important role in public employment decisions on derivative financial instruments. Enterprises using derivative financial instruments should have a training plan, constantly improve the qualifications and quality of personnel to have professional and qualified officials performing the operations when they use derivative financial instruments in production and business activities. There are many factors that influence the use and effectiveness of derivative financial instruments. Therefore, businesses listed on the Hanoi Stock Exchange in particular and Vietnamese businesses in general need to use derivative financial instruments in a flexible manner, especially to be aware in the circumstances or situations. In particular, the personnel who decide to use derivative financial instruments and experts must be able to flexibly apply hedging instruments to exchange rates, interest rates as well as commodity prices. In addition, businesses must be able to analyze and forecast the right decision in using derivative financial instruments without causing damage to the business.

For state agencies, it is necessary to complete the legal framework of derivative financial instruments. Although the legal documents on derivative financial instruments are not many, there are still many shortcomings that make it difficult for businesses to apply this tool. The Government should soon revise and promulgate documents on the mechanism of operation of commodity derivatives, interest rates, currencies and securities. The Government should promulgate standards on derivative financial instruments soon.

One of the reasons that derivative financial instruments have not become a commonly used tool in Vietnamese enterprises in general and enterprises listed on the Hanoi Stock Exchange in particular is the lack of instructions by the state derivative financial instruments. This makes businesses, suppliers as well as investors very concerned about the effectiveness of derivative contracts. State management agencies should support and coordinate with financial institutions providing derivative services and professional organizations to carry out communication and training programs to raise awareness and knowledge about knowledge and importance of derivative financial instruments in production and business activities of enterprises in current conditions.

\section{References}

Acharya, V. V., \& Richardson, M. P. (Eds.). (2009). Restoring financial stability: how to repair a failed system (Vol. 542). John Wiley \& Sons.

Adams, E. S., \& Runkle, D. E. (1999). The easy case for derivatives use: advocating a corporate fiduciary duty to use derivatives. William and Mary Law Review, 41(2), 595.

Ameer, R., \& bin Abdullah, A. (2011). A survey on the usage of derivatives and their effecton cost of equity capital. The Journal of Derivatives, 19(1), 56-71.

Antono, Z., Jaharadak, A., \& Khatibi, A. (2019). Analysis of factors affecting stock prices in mining sector: Evidence from Indonesia Stock Exchange. Management Science Letters, 9(10), 1701-1710.

Babak, P. (2008). The 10 largest trading losses in history. available at: http://seekingalpha.com/article/67420-the-10-largesttrading-losses-in-history (accessed October 12, 2008).

Baker, H. K., \& Haslem, J. A. (1974). The impact of investor socioeconomic characteristics on risk and return preferences. Journal of Business Research, 2(4), 469-476.

Beaver, W. H., Kennelly, J. W., \& Voss, W. M. (1968). Predictive ability as a criterion for the evaluation of accounting data. The Accounting Review, 43(4), 675-683. 
Bartram, S. M., Brown, G. W., \& Fehle, F. R. (2009). International evidence on financial derivatives usage. Financial Management, 38(1), 185-206.

Blanc, R. D. (1995). Developing internal controls to manage derivatives. INSIGHTS, April, 9.

Bezzina, F. H., \& Grima, S. (2012). Exploring factors affecting the proper use of derivatives. Managerial Finance, 38(4), 414435.

Bui, T. (2020). Stock holding decisions of foreign investors in emerging stock markets: A case study in Vietnam. Management Science Letters, 10(3), 625-630.

Mason, C., Kirkbride, J., \& Bryde, D. (2007). From stakeholders to institutions: the changing face of social enterprise governance theory. Management decision, 45(2), 284-301.

CFA (2009). CFA level 1 purposes and benefits of derivatives. available at: www.investopedia. com/study-guide/cfaexam/level-1/derivatives/cfa9.asp (accessed May 18, 2010).

Cochran, J. (2007). Carbon on credit: Global warming and the derivatives markets. available at: www.articlearchives.com/banking-finance/banking-lending-credit-services-consumer/ 347521-1.html (accessed October 10, 2008).

Cummins, J. D., Phillips, R. D., \& Smith, S. D. (2001). Derivatives and corporate risk management: Participation and volume decisions in the insurance industry. Journal of Risk and Insurance, 68(1), 51-91.

Das, S. (2006). Traders Guns and Money: Knowns and Unknowns in the Dazzling World of Derivatives, available at: ftp://ftp.pearsoned-ema.com/HPE_Samples/PressReleases/ 0273704745-PR.pdf (accessed December 10, 2008).

Dang, T., Phan, T., Tran, V., Tran, T., \& Pham, T. (2019). The impact of accounting disclosures on individual investors' decision making in Vietnam Stock Market. Management Science Letters, 9(13), 2391-2402.

Davidson, B. (2000). Auditing derivative strategies. The IIA Handbook Series, Institute of Internal Auditors, Altamonte Springs, FL.

Dodd, R. (2002). The role of derivatives in the East Asian financial crisis. International capital markets: Systems in transition, 447.

Hair, J. F., Ringle, C. M., \& Sarstedt, M. (2011). PLS-SEM: Indeed a silver bullet. Journal of Marketing theory and Practice, 19(2), 139-152.

Hair, J.F., Hult, G.T.M., Ringle, C., \& Sarstedt, M. (2013). A Primer on Partial Least Squares Structural Equation Modeling (PLS-SEM), Sage Publications Ltd, London.

Hair, J. F., Henseler, J., Dijkstra, T. K., \& Sarstedt, M. (2014). Common beliefs and reality about partial least squares: comments on Rönkkö and Evermann. Organizational Research Methods, 17(2), 182-209.

Hair, J. F., Hult, G. T. M., Ringle, C. M., \& Sarstedt, M. (2017). A Primer on Partial Least Squares Structural Equation Modeling (PLS-SEM), $2^{\text {nd }}$ ed., Sage: Thousand Oaks.

Henseler, J., Ringle, C.M., \& Sarstedt, M. (2015). A new criterion for assessing discriminant validity in variance-based structural equation modeling, Journal of the Academy of Marketing Science, 43(1), 115-135.

Henseler, J., Ringle, C.M., \& Sinkovics, R.R. (2009). The use of partial least squares path modeling in international marketing, in Sinkovics, R.R. and Ghauri, P.N. (Eds), New Challenges to International Marketing, Emerald Group Publishing Limited.

Hull, J. (2008). Options, Futures and Other Derivatives, $7^{\text {th }}$ ed., Prentice-Hall, Upper Saddle River, NJ.

John, J. F. (1992). Corporate governance and disclosure quality. Accounting and Business Research, 22(86), $111-124$.

Nguyễn Thu Thủy (2017), 'Một số giải pháp phát triển thị trường chứng khoán phái sinh Việt Nam', Tạp chí Kinh tế \& Phát triển, 244, 25-33.

Nguyen, M., Xuan, P., \& Bui, T. (2020). Causal relationship between banking system development and real estate market. Management Science Letters, 10(1), 41-52.

Pengelly, M. (2008). Survey reveals funds' lack of derivatives expertise. August 1, available at: www.risk.net/riskmagazine/news/1497769/survey-reveals-funds-lackderivatives-expertise (accessed March 12, 2009).

Pham, Q., Ho, T., Pham, D., \& Nguyen, H. (2020). Effects of corporate governance on high growth rate: evidence from Vietnamese listed companies. Management Science Letters, 10(7), 1553-1566.

Sharma, S. (2009). Role of financial derivatives in managing risk in financial markets: towards the complex exchange of risk, speculation, and fundamental value.

Sterling, R. (1970). Theory of the Measurement of Enterprise Income. Kansas, the University Press of Kansas.

Stulz, R. M. (2005). Financial derivatives. The Milken Institute Review, 20-31.

Tavakoli, J. (2001). Credit Derivatives and Synthetic Structures: A Guide to Instruments and Applications. $2^{\text {nd }}$ ed., Wiley, New York, NY.

Thuy, V., Thu, T., \& Viet, H. (2019). The impact of microeconomic factors on the abnormal return of listed stocks in Vietnam. Management Science Letters, 9(11), 1863-1874.

Tirole, J. (1988). The theory of industrial organization. Cambridge. CA, MIT Press.

Trần Mạnh Dũng (2014). 'Tính tuân thủ chuẩn mực lập báo cáo tài chính quốc tế: Kiểm tra giảm giá trị tại Hồng Kông'. Tạp chí Kinh tế \& Phát triển, 203(2), 131-139. 
Tran, T., Ha, X., Le, T., \& Nguyen, N. (2019). Factors affecting IFRS adoption in listed companies: Evidence from Vietnam. Management Science Letters, 9(13), 2169-2180.

Wernerfelt, B. (1984). A resource-based view of the firm. Strategic Management Journal, 5(2), 171-180.

Xuan, V., Thu, N., \& Anh, N. (2020). Factors affecting the business performance of enterprises: Evidence at Vietnam small and medium-sized enterprises. Management Science Letters, 10(4), 865-870.

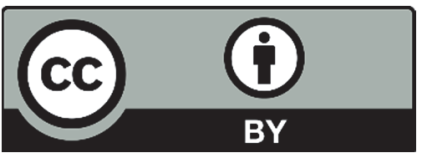

(C) 2020 by the authors; licensee Growing Science, Canada. This is an open access article distributed under the terms and conditions of the Creative Commons Attribution (CC-BY) license (http://creativecommons.org/licenses/by/4.0/). 